\title{
THE USE OF STRATEGIC MARKETING TOOLS FOR TERRITORIES TO DEVELOP THE DOMESTIC TOURISM RESOURCE POTENTIAL
}

\author{
Olena Sushchenko*, Doctor of Sciences (Economics), Professor \\ Nadiya Dekhtyar **, PhD (Economics), Associate Professor \\ Simon Kuznets Kharkiv National University of Economics \\ Iryna Chernysh"**, Doctor of Sciences (Economics), Professor \\ National University «Yuri Kondratyuk Poltava Polytechnic»
}

\begin{abstract}
* ORCID 0000-0002-2645-8015
** ORCID 0000-0001-7932-8620

***ORCID 0000-0001-6565-5292
\end{abstract}

\author{
(C) Sushchenko O., 2020 \\ (C) Dekhtyar N., 2020 \\ (C) Chernysh I., 2020
}

Стаття отримана редакиією 19.12.2020 p.

The article received by the reduction 19.12.2020.

Introduction. The need to realize the significant resource potential of Ukraine in the tourism industry makes the use of marketing tools for territories to develop the domestic tourism the actual problem. Development of destinations depends on how widely modern marketing techniques to increase the attractiveness of the territory and the level of competitiveness of its tourism services are widely used. The choice and use of innovative operational and strategic marketing tools for the domestic tourism resource potential development is an urgent issue for the current tourism market of Ukraine.

Analysis of recent research sources and publications. The issues of scientific substantiation of marketing aspects of territories development, tourism, services are of interest for such scientists as D. Aaker and E. Joachimsthaler [1], S. Anholt [2], L. de Chernacony [3], P. Kotler [4], J. Lambin [5], M. Porter [6] and others.

D. Cravens considers the development and implementation of a territory's marketing strategy as an ongoing process consisting of the stages of situational analysis, marketing strategy development, marketing program development, and marketing strategy implementation and management [7].

The issues of scientific research of tourist market development problems, including tourist destinations' marketing, are of interest for such Ukrainian scientists as O. Lubitseva [8], N. Letunovska [9], O. Romankin [10], Y. Rozhuk [11], I. Chernysh [12] and others.

Analyzing, systematizing and summarizing the main statements from the above scientific works, as well as taking into account current trends, it should be noted the growing attention to the domestic tourism development problems, its marketing and resource ensuring.

Setting the objectives. The aim of the article is to research of the features and to develop a set of recommendations for the use of strategic marketing tools for territories to develop the domestic tourism resource potential in Ukraine

Main material and results. Development and promotion of domestic tourism increases the competitiveness of the tourism sector, not only domestically, but also internationally. An important role in this is played by the tourism resource potential use and development. This issue is especially relevant today, when, as a result of the restrictions caused by the global pandemic, foreign tourist travels has practically stopped. Therefore, now travelers choose tourist destinations as close as possible to their place of permanent residence.

Accordingly, with the resumption of travel, in countries with a high share of domestic tourism, the tourism market revival and recovery will happen sooner. Hence, the development of domestic tourism should be a priority for Ukraine. Today, the world's largest tourism markets are China, the USA and India. This is due, primarily, the population in these countries and their geographical size. However, besides these, the 
countries also have the domestic tourism resource potential significantly developed, which is effectively used.

The domestic tourism resource potential and its development is determined by the tourism product that is created in this territory, its tourism infrastructure development, the tourist destination's brand, and the territory's promotion. All of these stages require appropriate marketing support based on the innovative marketing tools development and use, both operational and strategic.

Tourism - one of the largest industries in the world, which is developing dynamically. Over the past five years, one in four new jobs was created by the sector, making Travel \& Tourism the best partner for governments to generate employment. In 2019, Travel \& Tourism's direct, indirect and induced impact accounted for [13] (fig. 1):

- $\quad$ US \$8.9 trillion contribution to the world's GDP;

- $\quad 10.3 \%$ of global GDP;

- 330 million jobs, 1 in 10 jobs around the world;

- $\quad$ US $\$ 1.7$ trillion visitor exports (6.8\% of total exports, $28.3 \%$ of global services exports);

- $\quad$ US $\$ 948$ billion capital investment (4.3\% of total investment).

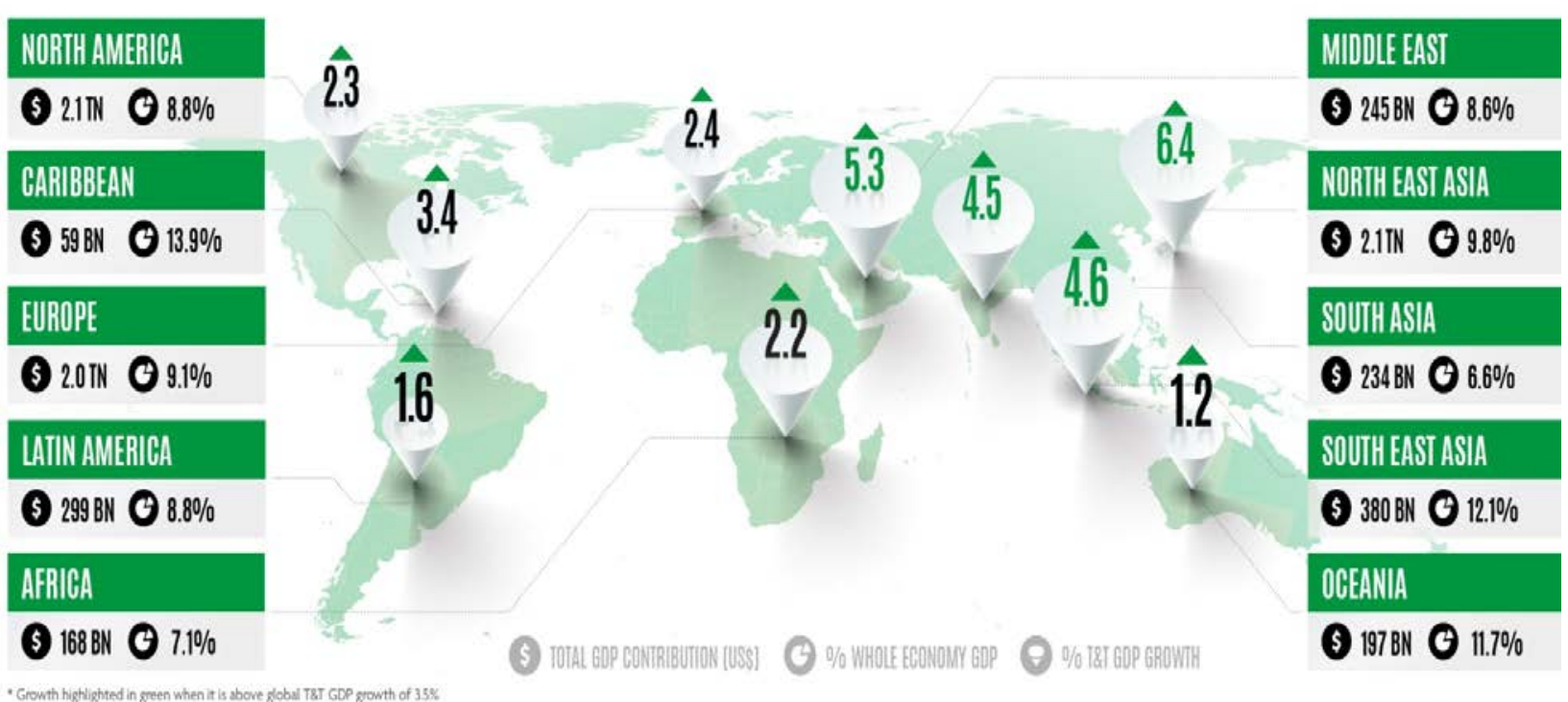

Fig. 1. Travel \& Tourism Regional Performance, 2019 [13]

However, the situation has changed radically as a result of the pandemic COVID-19, which caused a catastrophic impact on the tourism industry.

Global tourism suffered its worst year on record at the end of 2020, with international arrivals dropping by $74 \%$ according to the latest data from the World Tourism Organization (UNWTO). Destinations worldwide welcomed 1 billion fewer international arrivals in 2020 than in the previous year, due to an unprecedented fall in demand and widespread travel restrictions. This compares with the $4 \%$ decline recorded during the 2009 global economic crisis [14].

According to the latest UNWTO data, the collapse in international travel represents an estimated loss of USD 1.3 trillion in export revenues - more than 11 times the loss recorded during the 2009 global economic crisis. The crisis has put between 100 and 120 million direct tourism jobs at risk, many of them in small and medium-sized enterprises [14].

That's why we have to rethink and rebuild the tourism industry and its contribution to the world and national economies according to the new reality. One of the main goals is to create a more sustainable and resilient conditions for tourism industry that ensure the benefits of domestic tourism, its resource potential. It is important to use the strategic marketing tools for territories to develop and increase the domestic tourism resource potential.

J. Lambin in his scientific work notes that customer satisfaction (in this case, tourists) - is the core of marketing and the current economy [5]. However, the concept of need is the term, around which an endless debate, since it contains elements of subjective judgment based on morality or sometimes ideology. It is necessary to keep in mind the following facts:

- the constant appearance on the market of new products and brands; 
- the impact of continuous bright ever-changing advertising;

- the customer satisfaction relative stability, despite the marked improvement in living standards.

Due to its advantages, strategic marketing in the tourism industry is gaining in importance both from a theoretical and practical point of view.

However, the lack of fundamental research on strategic marketing in tourism at the macro level requires additional studies.

This is due, firstly, to the complexity of the tourism product, and secondly, with the integration in the system of marketing in tourism of different institutional units, the content of the strategic and operational marketing ultimate goals which are not the same (fig. 2).

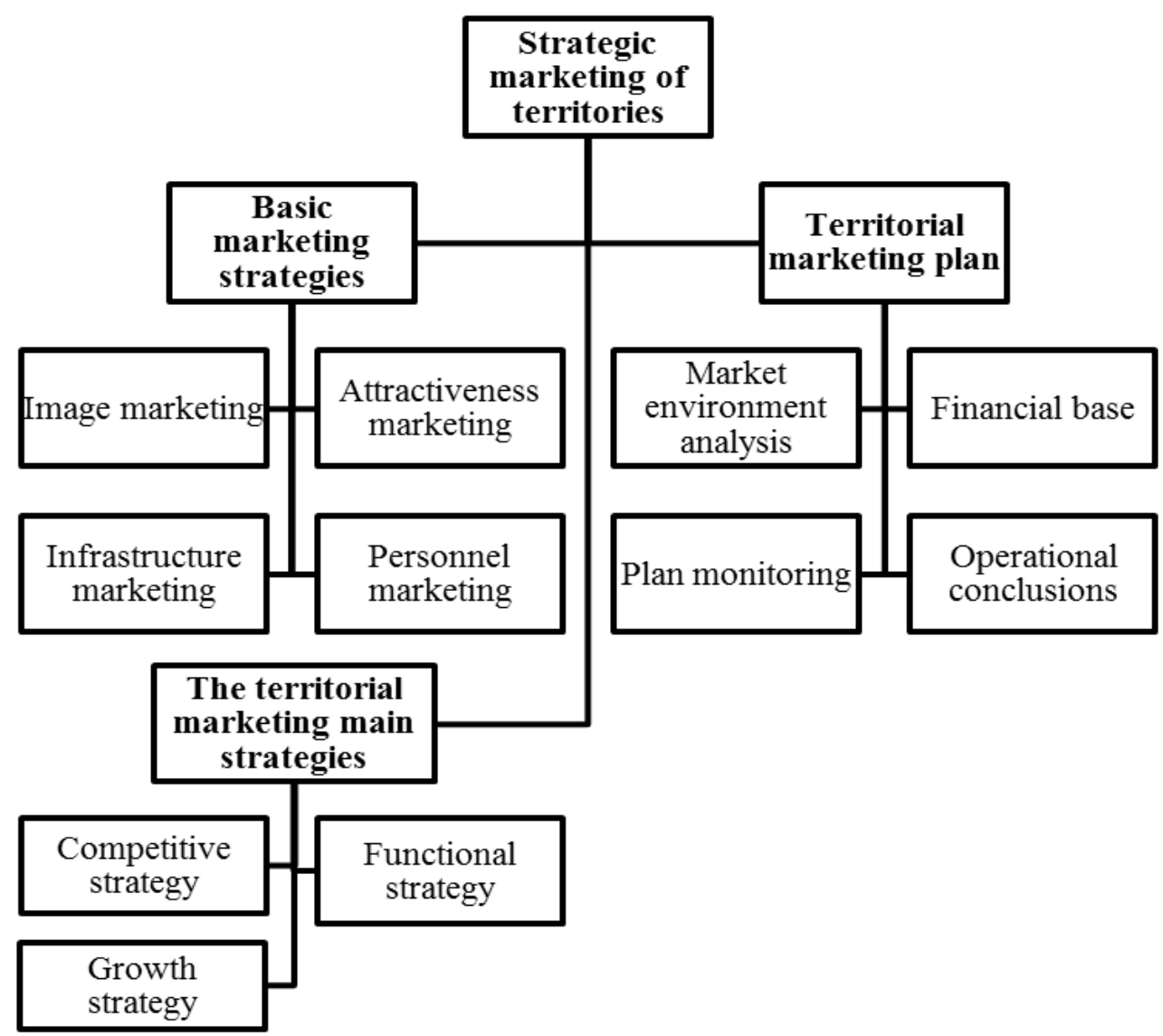

Fig. 2. Components of strategic marketing of territories

The relevance of tourism marketing is determined by the growing interest in marketing as a means of life support and the tourism market subjects' development; massive changes in consumer preferences and the new needs and lifestyle formation in their minds.

In current tourism services marketing, the branding of a territory as a tourist destination and local tourism products produced on it is also becoming increasingly important [15].

For the territory development as a tourist destination, it is necessary to mark the strategic marketing of territories "active phase" beginning, if up to this marketing tool has not been implemented or developed sporadically.

"Portfolio" matrix of the territory allows to see the currently successful and effective types of activities that are being implemented in this territory, as well as to predict which types of activities can be considered as perspective in the future [16].

Thorough knowledge of the market in the domestic tourism resource potential development context is an advantage for the territorial marketing and makes it possible to achieve the tourist destination's attractiveness due to its strengths. Attractiveness is also achieved through local resources, labor, agglomeration effect and an integrated brand. 
"Portfolio" strategy in the territorial marketing

\begin{tabular}{|l|l|l|}
\cline { 2 - 3 } \multicolumn{1}{c|}{} & $\begin{array}{l}\text { The most developed activities in } \\
\text { the territory today }\end{array}$ & \multicolumn{1}{c|}{$\begin{array}{c}\text { The least developed activities in the } \\
\text { territory today }\end{array}$} \\
\hline $\begin{array}{l}\text { Activities, the demand for } \\
\text { goods (services) of which } \\
\text { is growing at a high rate }\end{array}$ & $\begin{array}{l}\text { "Star" - types of activities (goods, } \\
\text { services), the demand for which } \\
\text { today and in the near future will } \\
\text { grow rapidly. }\end{array}$ & $\begin{array}{l}\text { "Question mark" - in which activities } \\
\text { (goods and services) should be directed } \\
\text { the limited resources available to obtain } \\
\text { high returns in the future. }\end{array}$ \\
\hline $\begin{array}{l}\text { Activities, the demand for } \\
\text { goods (services) of which } \\
\text { is growing at a low rate }\end{array}$ & $\begin{array}{l}\text { "Cash Cow" - activities (goods } \\
\text { and services), which today bring } \\
\text { the highest possible amount of the } \\
\text { territory total income. }\end{array}$ & $\begin{array}{l}\text { "Dog" - types of activities (goods, } \\
\text { services) that should be preserved for the } \\
\text { territory image or because of their great } \\
\text { social significance for the territory. }\end{array}$ \\
\hline
\end{tabular}
[17]:

These factors analysis is an important first step in the territorial marketing concept implementation

1. thorough analysis of the territory resources and its specific capabilities using SWOT analysis;

2. selection of an appropriate territorial positioning;

3. adaptation and / or creation of a new attractiveness factors, allowing to present an individual proposal in accordance with a given territory development concept;

4. constant study of potential markets through ongoing monitoring;

5. renovation and completion of the existing strategy in the framework of territorial development concept as a tourist destination.

To develop domestic tourism with the use of strategic marketing tools, it is necessary to very carefully diversify the tourist destinations development directions and choose the most effective marketing strategy, since domestic tourists already have a common image of some destination. Thus, an insufficiently correct analysis of resources, an incorrectly chosen conversion communication channel may not work.

The use of «classical» tools is effective in symbiosis with innovative ones to ensure a synergistic effect and create the territory's positive attractive image (fig. 3) [5].

The image marketing focuses primarily on the creation and dissemination of the territory's positive image. This strategy is relatively inexpensive as it does not require significant investment in infrastructure, economic reforms, etc. Its main focus is communication impact on potential consumers and dissemination of information about the strengths and advantages of the territory.

Important in this case is characteristic of each group of consumers, the definition of their specific expectations and needs.

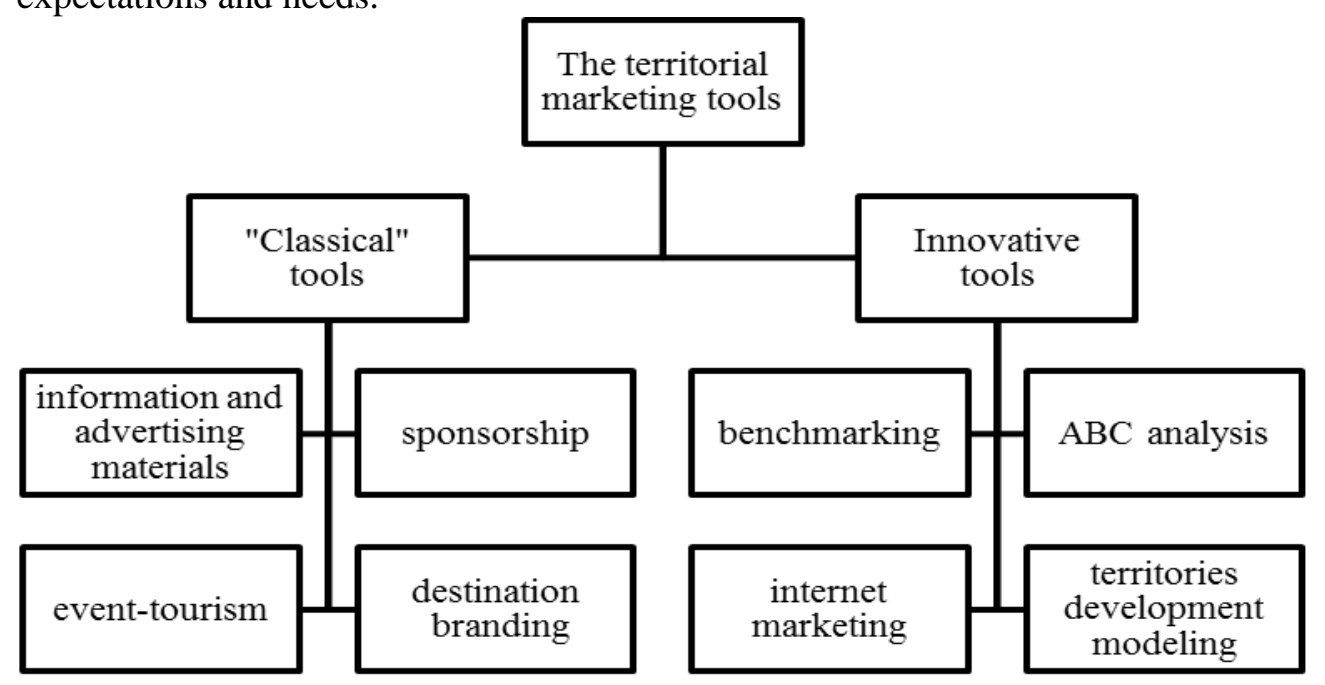

Fig. 3. The territorial marketing tools

For segmentation, it is necessary to consider:

- $\quad$ the function of needs - "what" is satisfied;

- $\quad$ technologies - "how" needs are met; 
- $\quad$ consumer groups - the "who" enjoys [16].

Among other things, when developing the content of territorial marketing as a tourist destination, it is necessary to take into account the ethnographic, political, economic reasons for the original and unique tourist product creation.

One of the examples of successful strategic marketing of territories (both in the context of domestic and inbound tourism) is the French Riviera (Cote d'Azur), to which, according to the Regional Tourism Committee of the Cote d'Azur, 13 million tourists come annually, accounting for 83 million overnight stays [18].

Unfortunately, there are no such successful examples on the territory of Ukraine yet. Among the domestic tourist destinations, Bukovel, Odessa region and city of Kyiv have a positive territory's image. Regarding the Kharkiv region, for example, its image can be characterized as weakly expressed. This territory as a tourist destination is little known to target groups of potential consumers, tourists. Among the main reasons are the lack of competitive advantages development, insufficiently effective advertising campaign and tourist attractions promotion, the tourist infrastructure insufficiently developed. Therefore, to form a positive image and the effective implementation of such marketing strategy as image marketing should be focused to form a communications policy and information flows.

In general, the Kharkiv region has a fairly significant resource potential for the domestic tourism development. Kharkiv owns a huge scientific potential, cultural heritage and investment attractiveness. Kharkiv is open to the whole world, it has 26 sister cities. The strategic goal of the city is to represent city of Kharkiv in the rating "Top-100 cities of the world" by 2030. Kharkiv is a promising center for exhibition and congress activities and is able to attract significant tourist flows, on condition of the tourism infrastructure development and the territory attractiveness marketing effective (fig. 4).

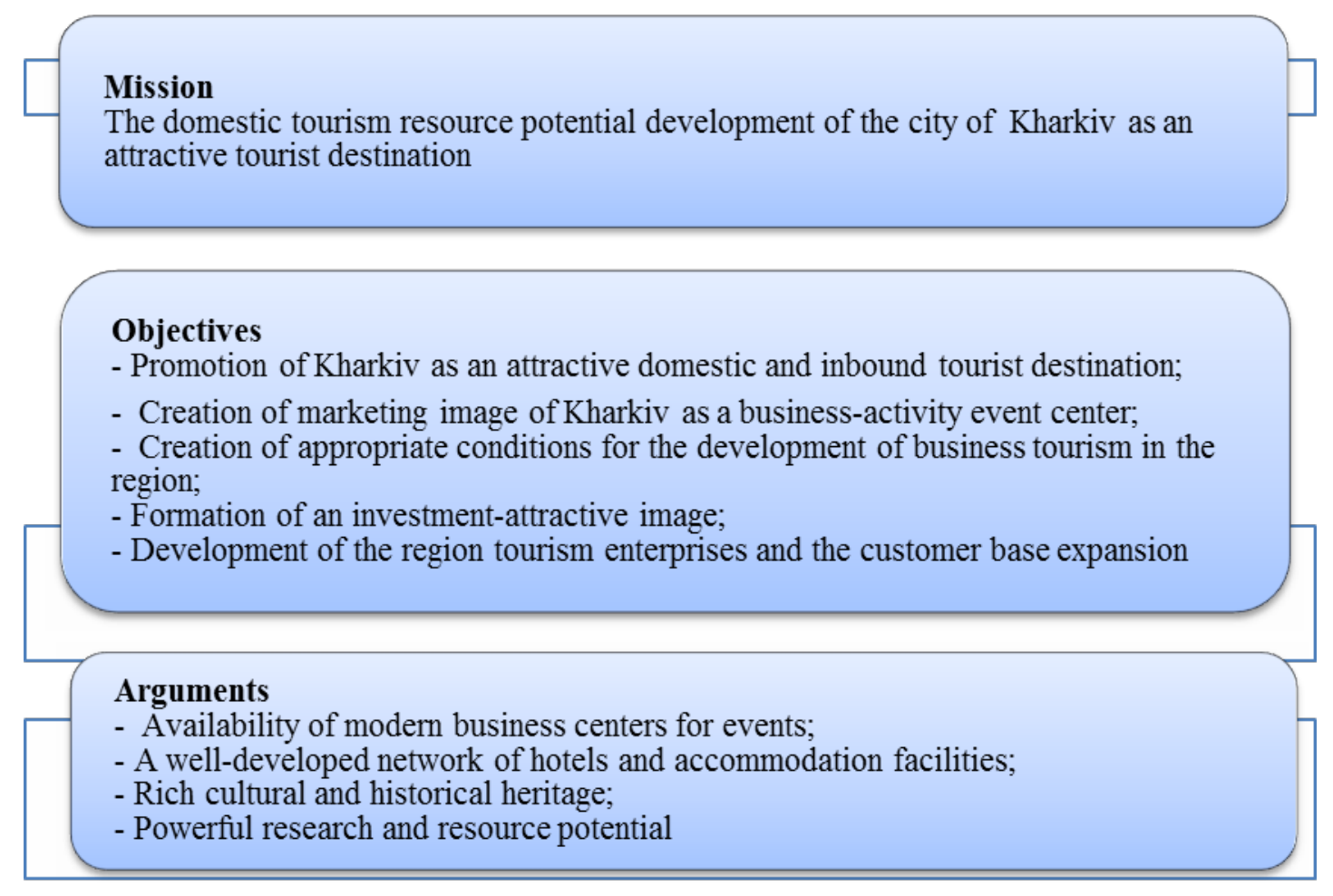

Fig. 4. Competitive advantages of Kharkiv as an attractive touristic destination

Conclusions. The use of strategic marketing tools for territories is a multi-level set of activities. The success of their implementation depends on cooperation and coordination between the different actors, stakeholders, government agencies etc. The use of effective and innovative tools for strategic marketing of territories should play a special role in positioning the territory as a tourist destination, determining the strategy of the authorities and the population to develop its advantages and reduce competitive disadvantages. The use of strategic marketing tools for the domestic tourism resource potential development makes sense in conjunction with the general strategy and concept of a country or region tourism development, taking into account the ethnographic, geographical, political and economic characteristics of 
the destination. In addition, it is extremely important to segment and cluster each consumer group for a more positive effect and creating the necessary territory's image.

\section{REFERENCES:}

1. Aaker, D.A. and Joachimsthaler, E. (2000) BrandLeadership. New York: Free Press [in English].

2. Anholt, S. (2007) Competitive Identity: The New Brand Management for Nations, Cities and Regions: Palgrave Macmillan [in English].

3. Chernacony de L. \& F. Dall’Olmo Riley (1998). Defining "brand": beyond the literature with experts' interpretations. Journal of Marketing Management, 14(5), 417-443 [in English].

4. Kotler, Ph. (1967) Marketing Management: Analysis, Planning and Control. Englewood Cliffs, N.J.: Prentice-Hall [in English].

5. Lambin, J., de Moerloose, C. (2016). Marketing stratégique et opérationnel: La démarche marketing dans l'économie numérique. Paris: Dunod [in French].

6. Porter, M.E. (1985) Competitive Advantage, Free Press, New York. [in English].

7. Cravens D. \& N. Piercy (2006) Strategic Marketing. McGraw-Hill [in English].

8. Lubitseva O.O. (2002) Rynok turystychnyh poslug (geoprostorovyj aspekt) [Tourism services market (geospatial aspect)]. K.: Alterpres [in Ukraine].

9. Letunovska N.Ye. (2019) Innovative marketing approaches to promote the consumption of tourist product. Proceedings of the Conference "Corporate governance: strategies, processes, technology (October 25th, 2019). Leipzig, Germany : Baltija Publishing, 73-75 [in English].

10. Romankin O.V., Davidova O.G. (2017) Osoblyvosti marketyngovyh komunikaciy u turystichniy sferi: svitovy dosvid [Features of marketing communications in the field of tourism: world experience]. Prychornomors'ki ekonomichni studiï. Vol. 13-1, 22-26 [in Ukraine].

11. Rozhuk Ya.V. Osoblyvosti vykoristannya marketyngovyh komunikacyy u galuzi turizmu [Features of marketing communications in tourism]. Retrieved from: http://www.vestnikeconom.mgu.od.ua/journal/2017/26-1-2017/23.pdf [in Ukraine].

12. Chernysh I.V. \& Makhovka V.M. (2019) Features of the tourism enterprises management in the conditions of exacerbation. Ekonomika i Rehion [Economy and region]. № 3(74), $57-64$ [in English].

13. Economic Impact Reports (2019). Retrieved from: https://wttc.org/Research/Economic-Impact [in English].

14. International Tourism and covid-19. Retrieved from: https://www.unwto.org/tourism-covid$\underline{19}$ [in English].

15. Kavaratzis, Mihalis \& Ashworth, G.J. (2005). City branding: An effective assertion of identity or a transitory marketing trick? Tijdschrift voor conomische en Sociale Geografie, 96, 506-514 [in English].

16. Sachuk T.V. (2017) Territorial'nyj marketing: teorija i praktika [Territorial marketing: theory and practice]. M : INFRA-M [in Russian].

17. Tabet-Aoul, M. (2009) Le marketing territorial, un outil de développement local. Retrieved from: https://cutt.ly/qktbn8i [in French]

18. Tourism key figures (2019). Côte d'Azur France. Retrieved from: http://www.cotedazurtouriscope.com/pdf/chiffres/2019/Chiffres-cles-2019-F.pdf in English].

UDC 338.48

JEL Z 32

Сущенко Олена Анатоліївна, доктор економічних наук, професор. Дехтяр Надія Анатоліївна, кандидат економічних наук, доцент. Харківський національний економічний університет імені Семена Кузнеця. Черниш Ірина Володимирівна, доктор економічних наук, доцент, директор Навчально-наукового інституту фінансів, економіки та менеджменту. Національний університет «Полтавська політехніка імені Юрія Кондратюка». Використання інструментів стратегічного маркетингу територій для розвитку ресурсного потенціалу внутрішнього туризму. Мета статті полягає у дослідженні особливостей та формуванні підходу до використання інструментів стратегічного маркетингу територій для розвитку ресурсного потенціалу внутрішнього туризму України. Визначено, що розвиток та популяризація внутрішнього туризму підвищує конкурентоспроможність туристичного сектора країни не лише на внутрішньому ринку, але й на міжнародному. Зазначено, що в країнах із високою часткою внутрішнього туризму пожвавлення й відновлення туристичного ринку після катастрофічного впливу пандемії COVID-19 відбудеться 
раніше. Показано, що розвиток ресурсного потенціалу внутрішнього туризму визначається туристичним продуктом, туристичною інфраструктурою території, iii промоцією, брендом туристичної дестинації. Це потребує використання інноваційного інструментарію стратегічного маркетингу та відповідного маркетингового забезпечення. Визначено складові стратегічного маркетингу територій. Запропоновано використання «портфельної» стратегії в територіальному маркетингу. Обгрунтовано необхідність досконалого вивчення ринку в контексті розвитку ресурсного потенціалу внутрішнього туризму, що визначить сутність маркетингу територій $\mathrm{i}$ дозволить досягти привабливості туристичної дестинації. Надано загальний інструментарій територіального маркетингу. Обгрунтовано, що Харківський регіон має значний ресурсний потенціал для розвитку внутрішнього туризму. Харків має величезний науковий потенціал, культурну спадщину та інвестиційну привабливість. Запропоновано для формування позитивного іміджу Харкова як туристичної дестинації реалізовувати стратегію іміджевого маркетингу на основі формування відповідної комунікаційної політики й інформаційних потоків. Визначено конкурентні переваги Харкова як привабливої туристичної дестинації, перспективного центру виставкової та конгресної діяльності.

Ключові слова: стратегічний маркетинг, ресурсний потенціал, маркетинг теориторії, бренд дестинації, внутрішній туризм, регіон.

UDC 338.48

JEL Z 32

Sushchenko Olena, Doctor of Sciences (Economics), Professor. Dekhtyar Nadiya, PhD (Economics), Associate Professor. Simon Kuznets Kharkiv National University of Economics. Chernysh Iryna, Doctor of Sciences (Economics), Professor. National University «Yuri Kondratyuk Poltava Polytechnic». The Use of Strategic Marketing Tools for Territories to Develop the Domestic Tourism Resource Potential. The aim of the article is to research of the features and to develop a set of recommendations for the use of strategic marketing tools for territories to develop the resource potential in Ukraine. The use of tourism resource potential is played an important role in the domestic tourism development. It is shown that the domestic tourism resource potential development is determined by the tourist product, the tourist infrastructure, the territory promotion, and the destination brand. The use of strategic marketing innovative tools and marketing support is grounded. The components of strategic marketing of territories are determined. The use of "portfolio" strategy in territorial marketing is proposed. The general tools of territorial marketing are given. It is substantiated that the Kharkiv region has a significant resource potential for the domestic tourism development. To form a positive image of Kharkiv as a tourist destination the implementation of an image marketing strategy is proposed. The competitive advantages of Kharkiv as an attractive tourist destination, a perspective center of exhibition and congress activities are determined.

Key words: strategic marketing, resource potential, territorial marketing, destination branding, domestic tourism, region. 